\title{
The Community-Engaged University: The Case of Universities in Ethiopia
}

\author{
Peter van der Sijde \\ VU University Amsterdam \\ Marissa Popma \\ VU University Amsterdam \\ Kora Tushune \\ Jimma University
}

Throughout the world, higher education institutions are facing the challenge of engaging more closely with their surrounding communities, thereby developing an intellectual foundation for such engagement and integrating the key aspects of the university's mission: teaching, research and community service. This study tracks the development of the concept of community engagement in Ethiopian higher education. We will focus on the current state and required characteristics for community engaged universities in the Ethiopian context. In doing so, we will try to develop and strengthen an understanding of how Ethiopian universities work with their local communities. The article includes one Ethiopian university as case study to illustrate the processes and outcomes of embedding community engagement in Ethiopian higher education.

\section{INTRODUCTION}

Ethiopia is currently engaged in a highly ambitious effort to expand and reform its higher education system in order to contribute more directly to its national strategy for economic growth and poverty reduction (World Bank, 2003; Yizengaw, 2007). The Ethiopian government policy in higher education encompasses two major aspects: increasing equitable access and ensuring relevance and quality of education. A rapid expansion of higher education has been undertaken during the last five years. Twelve new public universities were established in addition to the nine already established universities. This expansion has taken into account equitable distribution of the higher education institutions among the different regions of the country. This equitable distribution serves the purpose of regional capacity building in terms of contributing to regional and local socio-economic development issues to strengthen decentralization.

These recent developments also increase the potential for strengthening the (science and technology) links between Ethiopian higher education institutions, the communities, the labour market and industry. While universities can interact with their communities in a range of ways, 
university-community engagement specifically implies collaborative relationships leading to productive partnerships that yield mutually beneficial outcomes. A university's community could include many groups such as businesses, industries, professional associations, schools, governments, alumni, indigenous and ethnic communities as well as groups of local citizens. This has become known as Community Engagement (CE) and, together with teaching and learning and research form the three core functions of a university, whereas CE is an elaboration of the "third task". These three core functions should complement each other in an integrated service to the county, the region and the world of scholarship. CE thus enhances social awareness that can be reflected in the teaching at the university. CE also leads to research topics and research outcomes that can be implemented to improve the quality of life of the population. According to the Ethiopia's Education Sector Development Program, one of the main goals of higher education in Ethiopia is to develop responsible and competent citizens who meet the quantitative and qualitative demand for a high-level trained labour force based on the socioeconomic development needs of the country. One of the most important responsibilities of educational institutions in Ethiopia is a commitment to support community development in a practical and workable way, aiming to provide some relief from inequality, poverty and social problems. Engaged universities are, therefore, essential for Ethiopia's economic and social future. University wide, institutionalized and sustainable commitment to community engagement and research is not only a necessity but also a priority if Ethiopian higher education is to further improve and strengthen its quality and relevance. As stated by a former State Minister for Higher Education, Yizengaw (2007) in his book on Ethiopian higher education, universities in Ethiopia should increasingly prepare themselves to respond to societal needs in their education, training and research activities in order to sustain societal and public support. According to Yizengaw (2007) the links between research and teaching have to be clearly articulated and research should be conducted towards the overall renewal of the universities to deliver social expectations and to provide relevant and quality education and training to its students. The higher education proclamation, which summarizes the policy and strategy directions for universities in Ethiopia, states that universities are increasingly expected to undertake and disseminate research and studies based on national priority challenges. This is considered to be essential for bringing about improvements in the livelihood of society and overall reduction of poverty in the country. The World Bank report on the status of universities in Ethiopia (2003) also observed the need for Ethiopian universities to contribute to the alleviation of social and economic development challenges of society through research, studies and community services. Ethiopian universities have the potential to become a viable partner to society if faculties and the organizational entities of the universities carry out more research trough the expansion of quality graduate programs with appropriate support from government and stakeholders (Teshome, 2004; 2006b). Universities need to undertake research and studies to enable students to become problem solving citizens and knowledgeable experts. The extent to which HEIs build and strengthen linkages with the wider public, industry and services determines its relevance to society and social responsibility.

This article explores the shape of the concept of community engagement has taken in Ethiopian Higher Education. We will try to find an answer to the question "how do Ethiopian universities shape their engagement with the community (challenge) in order to obtain synergy (opportunity) with the other two tasks research and teaching?" In finding an answer we will first explore the extent to which $\mathrm{CE}$ has taken shape within the nine established universities in Ethiopia. We will also focus on one specific case of a community engaged university, Jimma 
University; we will explore how the concept has been interpreted and operationalized within this university and what the perceived (dis)advantages and experiences are. This article is organized as follows, first a description will be given of what constitutes an engaged university. In the following section we will go into a conceptual model for CE for higher education. We then present the results of a study into (aspects of) the current status of CE in the universities in Ethiopia. Then, we zoom in into one of Ethiopian universities that is already actively engaged with its community and developed and implemented its concept of Community-Oriented Education as its interpretation of CE. In the discussion we will elaborate on the possibilities of making CE more effective in Ethiopian higher education. In the final section we will draw our conclusions from the above.

\section{THE EVOLUTION OF THE CONCEPT OF ENGAGED UNIVERSITY: THE JOURNEY OF AN IDEA}

In higher education more new concepts on the nature of universities have risen than in all the centuries before. Grit (2000) identified three different types of universities: the classical university, the critical university that rose in the late $60 \mathrm{~s}$, and the entrepreneurial university that was first labeled by Davies in 1987 and brought to blossom by Clark (1997). In his first book Clark (1997) identifies five European universities as entrepreneurial; in his second book (Clark, 2004) he describes eight more entrepreneurial universities - there is only one African university mentioned, the Makarere University in Uganda. Also other new types of universities were identified, e.g. the engaged university (Kellogg Commission, 1999), that focused on the role of a university in its community. Kellogg Commission refer to "engagement" as "redesigned teaching, research, and extension and service functions that are sympathetically and productively involved with the communities universities serve, however community is defined" (p.27). Powell (2008) introduced the concept of the "creative university" that incorporates elements of both the engaged as well as the entrepreneurial university. Some authors have already outlined the contours of a university of the future; e.g. Wissema (2009) in his book on the "third generation university". The concept, or rather the idea, has changed over the years since it was first introduced and journeyed through the world of academia as well as the scientific world. The (new) concepts in the literature are an indication of new roles universities have to play in their environment to shape its tasks set (in most countries) by law: research, teaching, and ... this third task. This third task of universities and how CE is shaped, is the topic of this contribution, thereby focusing on Ethiopia a country that is undergoing a rapid transformation and expansion of its higher education sector.

\section{Conceptual Models for Community Engagement in Higher Education}

Community engagement is a term that is in flux and in fashion. The notion of $\mathrm{CE}$ has been a result of a shift in the terminology used by higher education stakeholders. Its roots can be traced back to Davis (1987) who introduced the "entrepreneurial and adaptive universities" in his report on a study visit to universities in the USA. He observed four trends in US higher education at that time the universities had to cope with:

(1) A demographic trend: universities have to adapt to the needs of other types of students than just the ordinary full-time students. Universities e.g. have to deal with part-time students and older students. 
(2) A financial turndown: tighter budget processes, fewer government funds, etc.

(3) A relation with industry: in general this means the breakdown of the "ivory tower" in favour of relations and interaction with industry.

(4) A severe competitive market: a severe competition between universities, competition with the non-education sector for students, and competition for research funds.

Davis observed "recognition by universities of the need to play a helpful role in the regional economic development and the provision of an integrated university support for the community, especially where that community is under stress" (Davies, 1987, p. 19). In other words, universities that want to survive in a competitive environment need to take the community in which it is located on board.

Clark (1997) takes over the baton from Davis and elaborated the concept and re-labels most of Davis" trends into five characteristics of entrepreneurial universities:

- A strengthened steering core; this concerns the internal organization of a universities and is about leadership and vision.

- An expanded developmental periphery; this is about how a university interacts with its environment and community; via a special organizational unit (a transfer office) or is it integrated in research and teaching - nevertheless it should be identifiable as a unit or as a function within the university.

- A diversified funding base. A university should not only depend on government funds, it should attract other funds, e.g. from the community, industry, international bodies and NGOs.

- A stimulated academic heartland. A university should have a backbone in research as strong as possible. It should stimulate interdisciplinary and transdisciplinary research (and teaching)

- A new institutional ideal. In an entrepreneurial university there ought to be an atmosphere of enterprising behaviour, entrepreneurship and innovation in all the layers of the organization.

In the descriptions of the characteristics Clark talks about the environment; the community is not explicitly mentioned. The community, however, is at the centre of the thoughts that the Kellogg Commission put down to paper writing about the "engaged university". According to this Commission an engaged institute has to accomplish the following three things:

1. It must be organized to respond to the needs of today's students and tomorrow's, not yesterday's.

2. It must enrich students" experiences by bringing research and engagement into the curriculum and offering practical opportunities for students to prepare for the world they will enter.

3. It must put its critical resources (knowledge and expertise) to work on the problems its community faces.

Community engagement should be a core value of every university (Association of Commonwealth Universities, ACU, 2001). In the Association's consultative paper, this proposition is unpacked as follows: Engagement implies strenuous, thoughtful, argumentative interaction with the non-university world in at least four spheres: setting universities" aims, 
purposes and priorities; relating teaching and learning to the wider world; the back-and-forth dialogue between researchers and practitioners; and taking on wider responsibilities as neighbours and citizens (ACU, 2001: i). Community engagement can take many different forms and shapes within the context of higher education. These forms include distance education, community based research, participatory action research, professional community service, and service learning. In its fullest sense, $\mathrm{CE}$ is the combination and integration of service with teaching and research related and applied to indentified community development priorities (Bringle 1999, Bringle \& Hatcher 2004), an elaboration of the "third task" of universities.

\section{Benefits of Community Engagement}

Communities can benefit in various ways from their interactions with universities. Some of the benefits are enhanced human and social capital development, accelerated economic growth, improved professional and intellectual infrastructure in communities, progress towards sustainability and research outcomes that can benefit the social, economic, environmental and cultural dimensions of society (Bender 2008). Moreover, the development of a knowing and active citizenry can deliver greater corporate and community responsibility. This can, in turn, drive social cohesion and social change, generate informed debate on issues of significance to communities and it can improve their quality of life. Communities can benefit from engaged teaching and learning when, for instance, service learning involves undergraduates undertaking public good activities in the communities as part of their program of study. Whilst the community clearly benefits as a result of their activity, students involved in this type of engaged learning develop important skills in project management, team work and communication. The universities themselves can also benefit from effective engagement with their communities. For instance, students" learning outcomes will be enhanced through curricula that are relevant to community issues and priorities. The development of increased opportunities for student experiential learning will benefit students as well as universities by ensuring both are alive to contemporary issues and needs. Engagement should therefore be considered a core activity of universities and not as a separate undertaking.

\section{Community Engagement in the Established Universities in Ethiopia}

Ethiopia is currently engaged in a highly ambitious effort to re-align its higher education system in order to more directly support its national strategy for economic growth and poverty reduction. The Ethiopian Government has a vision of vastly increasing the participation of students in universities. While growths in the number of enrolment figures are remarkable the need to assure quality against the massification of higher education and the meeting of new expectations in terms of the employability of graduates are major challenges facing the Ethiopian higher education.

It is observed that the performance of university graduates in the work place was not as much as expected and should be. Most graduates were good in the theoretical knowledge but poor in skills and in the application of the knowledge they gained from the universities into the world of work. The focus on quality also encompasses relevance, so that students have practical problemsolving skills as well as theoretical knowledge. This requires improvements to teaching and research, greater responsiveness to the labour market and careful curricula review in terms of relevance to Ethiopia's needs. 


\section{METHOD}

Twenty-two respondents of the nine longer-established universities filled in the questionnaire. The respondents were all (senior) academic staff and some of them are or were in the past in a management position. The following research questions guided the research design of the questionnaire: What does Community Engagement involve in the perception of academic staff in Ethiopia's universities? A questionnaire has been distributed to the nine ("old") universities. The questionnaire is an operationalization of the dimensions of Clark's "entrepreneurial university" (1997), Holland's "commitment to service" (1997) and the Kellogg Commission's "engaged university" (1999). This questionnaire (see Table 1) is used to gain more insights in the current challenges and opportunities that Ethiopian universities experience and perceive in relation to community engagement.

TABLE 1

CONCEPTS AND TOPICS IN THE QUESTIONNAIRE

\begin{tabular}{|c|c|c|}
\hline Concepts & Source & Questionnaire topics \\
\hline Strengthened steering core & Clark (1997) & Mission of the university \\
\hline $\begin{array}{l}\text { Expanded developmental } \\
\text { periphery }\end{array}$ & & $\begin{array}{l}\text { University and community: staff, } \\
\text { students, community }\end{array}$ \\
\hline Diversified funding base & & Streams of income \\
\hline Commitment to service & Holland (1997 & $\begin{array}{l}\text { Responsiveness of research and } \\
\text { education to specific needs }\end{array}$ \\
\hline \multirow[t]{4}{*}{ Expectations from $\mathrm{CE}$} & Kellogg & Education \\
\hline & $\begin{array}{l}\text { Commission } \\
\text { (1999) }\end{array}$ & Research \\
\hline & & University \\
\hline & & Personal \\
\hline
\end{tabular}

\section{RESULTS}

The results of the questionnaire indicate, that the universities of the respondents all are involved in the three major activities of a university: research, teaching and "community engagement". According to some respondents these activities are explicitly mentioned in the mission of the universities; even the respondents who reply that it is not explicitly mentions indicate that it is implied (see Table 2). 
TABLE 2

ASPECTS OF THE UNIVERSITY MISSION AS MENTIONED

BY THE RESPONDENTS $(n=22)$

\begin{tabular}{lcc}
\hline & $\begin{array}{c}\text { Explicitly } \\
\text { mentioned }\end{array}$ & Implicitly mentioned \\
\hline Research & 21 & 1 \\
Education & 20 & 2 \\
Community engagement & 19 & 3 \\
\hline
\end{tabular}

This is an important finding, since all respondents mention that the university recognizes community engagement as an important task of a university and its mission in society and of a similar importance as research and teaching. All universities receive most of their financial resources for all its activities from the government. A second source of income (see Table 3) comes from large companies, and the community is also a source of income. In this study we have not asked for the nature (structural or ad-hoc income) nor the amount of money generated via the community.

TABLE 3

INCOME OF THE UNIVERSITY AS MENTIONED BY THE RESPONDENTS

\begin{tabular}{lc}
\hline & $\begin{array}{c}\text { Mentioned by } \\
\text { respondents } \\
(\mathrm{n}=22)\end{array}$ \\
\hline Income generated from the government & 19 \\
Income generated from generated from large companies & 12 \\
Income generated from the community & 7 \\
Income generated from endowments & 5 \\
Income generated from national research foundations & 4 \\
Income generated from other sources & 9 \\
\hline
\end{tabular}

The focus of the questionnaire is on the involvement of the university with its community and the respondents indicate that a large group of staff as well as students is involved in the community (see Table 4); the community, however, scores lower in the perception of the respondents, than staff and students. Nevertheless, the results of the questionnaire indicate that the (old) universities, for a large part, are involved in community engagement. 
TABLE 4

UNIVERSITY AND COMMUNITY

\begin{tabular}{lc}
\hline & $\begin{array}{c}\text { Mentioned by } \\
\text { respondents } \\
(\mathrm{n}=22)\end{array}$ \\
\hline Staff is involved in community activities & 18 \\
Students are involved in community activities & 17 \\
Community is involved in the university & 12 \\
\hline
\end{tabular}

The involvement of the university with its community is primarily via education (see Table 5) and less via research. The data show that education is responsive to the needs of students, the community and the SMEs. The responsiveness to the needs of the community is of interest and the number of community-based programs shows an interesting discrepancy. The percentage of community-based research is somewhat higher; interesting to note, is the responsiveness to the large companies as well as to the needs of the community for research. Most respondents added extra information on the involvement in CE of their universities indicating barriers, e.g. there is the barrier of remuneration to the students from the community. Opportunities for CE are in some universities, because new institutions - extended developmental peripheries (e.g. a partnership office or other interface institutions) are created. Notwithstanding the barriers, all respondents see opportunities (co-learning, involvement in community activities from the first year onwards), but recognize that sometimes it is not that strong represented in the teaching and research activities.

TABLE 5

RESPONSIVENESS OF RESEARCH AND EDUCATION TO SPECIFIC "NEEDS"

\begin{tabular}{lcc}
\hline & $\begin{array}{c}\text { Rese } \\
\text { arch }\end{array}$ & $\begin{array}{c}\text { Educ } \\
\text { ation }\end{array}$ \\
\hline Responsive to the needs of the students & 7 & 18 \\
Responsive to the needs of the community & 10 & 18 \\
Responsive to the needs of SMEs & 11 & 18 \\
Responsive to the needs of large companies & 10 & -- \\
University has some community-based research programmes & --- & 8 \\
University has some community-based teaching programmes & & 17 \\
\hline
\end{tabular}


The expectations of respondents with and without community engagement experience (see Table 6) do not differ, which raises the question to why the engagement is not incorporated in all university tasks. Both experienced and non-experienced respondents indicate that they expect a lot from community involvement to enrich both teaching and research. They also see a contribution to the prestige of the university and on a personal level they (expect to) feel a sense of accomplishment.

TABLE 6

EXPECTATIONS FROM COMMUNITY ENGAGEMENT

\begin{tabular}{|c|c|c|c|}
\hline & & $\begin{array}{l}\text { Respond } \\
\text { ents with } \\
\text { experience* }^{*} \\
(\mathrm{n}=11)\end{array}$ & $\begin{array}{l}\text { Respond } \\
\text { ents without } \\
\text { experience* } \\
(\mathrm{n}=11)\end{array}$ \\
\hline \multirow[t]{4}{*}{ Education } & New materials for class & 9 & 8 \\
\hline & Revision of teaching methods & 10 & 10 \\
\hline & Enhanced student learning & 11 & 11 \\
\hline & Changes in curriculum & 9 & 10 \\
\hline Research & Engagement leads to publications & 9 & 8 \\
\hline \multirow[t]{3}{*}{ Collaboration } & Collaborations with the community & 9 & 8 \\
\hline & Collaborations with SMEs & 11 & 6 \\
\hline & Collaborations with large enterprises & 8 & 5 \\
\hline \multirow[t]{4}{*}{ University } & Increased ability to serve clients & 10 & 9 \\
\hline & Increased volunteer participation & 11 & 9 \\
\hline & Enhanced number of offerings & 10 & 9 \\
\hline & Contribution to prestige & 9 & 9 \\
\hline Personal & Sense of accomplishment & 10 & 9 \\
\hline
\end{tabular}

* The respondents were asked whether or not they had experience with activities in the community as an academic

\section{DISCUSSION}

Although the respondents mention that $\mathrm{CE}$ is incorporated in their mission statement, not many institutes have developed (or translated) an understanding of the potential that CE holds for transforming higher education in relation to societal needs, and for producing graduates with a sense of civic responsibility and an ability to apply the theory of their disciplines to local development issues. Woldetensae (2006) mentions that the linkage of university and industry in 
Ethiopia has been traditionally weak and the cooperation between them is not sufficiently developed; this study supports this observation. With respect to a study by Ashcroft (2005) that indicates a lack of match between Ethiopian employer as a stakeholder on the one hand and the curriculum, pedagogy and assessment methods commonly developed by the universities on the other, our study shows some improvement: the respondents indicate that education is (becoming) more responsive to the needs of the community. Research in Ethiopian higher education is not sufficiently linked to industry (see Table 5). Many higher education institutions and industries seem to be working in isolation of each other. CE could be a vehicle for universities to be more responsive to its stakeholders. From the answers to the questionnaire can be deducted that $\mathrm{CE}$ is expected both to enrich the experiences of the students, and of the academic staff. Not only do the respondents expect this, half of the respondents already experience this. From the questionnaire it has not become clear whether or not the university has committed resources (knowledge, expertise, money) for CE. The results show that all ingredients for a communityengaged university are present in the "old" Ethiopian universities. According to Czariawska and Joerges (1996) "ideas" that travel are first to be disembedded and then reembedded: the data on the old Ethiopian universities show, that they are in the process of reembedding, a process that is not completed (yet) as shown by the data in Table 6. Engagement will change the university's climate into a more entrepreneurial and community-engaged one, that will result in a more diversified funding base (not just government). Some universities are also in the process of implementing an expanded developmental periphery. The new institutional idea that is developed in Ethiopia could be labeled as "the engaged entrepreneurial university": a university well embedded in the region exploiting its entrepreneurial potential.

\section{COMMUNITY ENGAGEMENT AT JIMMA UNIVERSITY}

Jimma University started operating in 1997 on the foundation and in the campus of former Jimma Institute of Health Sciences (JIHS) comprising of four founding faculties, namely, Faculty of Public Health, Faculty of Medical Sciences, Faculty of Business and Economics, and Faculty of Technology; however, its establishment regulation was issued in 1999 incorporating the former Jimma College of Agriculture (JCA), one of the pioneering agricultural technical schools in the country that was established in 1952. Five years later, Jimma Hospital, which had been the property of Oromia Regional Health Bureau and the only referral hospital in south western part of the country, was handed over to Jimma University and became under the jurisdiction of Jimma University. In what can be considered as an extraordinary decision, Ministry of Education decided to handover Ambo College of Agriculture, one of pioneer agricultural training colleges, to Jimma University in 2001 which remained under the University until mid-2009, when the college was promoted to a full university status and became independent of Jimma University. The University is located $360 \mathrm{~km}$ southwest of Addis Ababa, capital of Ethiopia, in Jimma town. Currently Jimma is the center of Jimma Zone of Oromia Regional State, the largest and most populous state in Ethiopia. It is one and the prominent of five Gibe States that flourished in the south western part of Ethiopia during the $18^{\text {th }}$ and $19^{\text {th }}$ centuries. King Abajifar Abamogol was the last and most powerful of the kings that ruled these states when they became part of main Ethiopian empire. Besides its historical significance Jimma is the homeland of Coffee Arabica before it was spread to different parts of the world.

Though Jimma University is one of the young universities that are just over ten years old, the constituent institutions are older - they are 35-58 years old making it one of the oldest in the 
country. Today, Jimma University is the second largest university in the country after Addis Ababa University taking into account the number of study programs, student and staff population and level of the infrastructure development. It is still in a fast expansion phase with new undergraduate and graduate programs being launched every year and a number of infrastructure being put in place to cope with the this unprecedented expansion.

\section{Educational Philosophy of Jimma University}

Jimma University adopted educational philosophy of Community-Oriented Education (COE), or Community Based Education (CBE) as it is referred to in Jimma University. The philosophy has its origins in the former Jimma Institute of Health Sciences (JIHS), the founding institution of Jimma University, and is the national pioneer in adopting, nurturing and sponsoring the innovative CBE approach in Ethiopia applying it, first, in medicine and health science disciplines and then expanding the approach to all disciplines of study in the University. It has been a member of international network of innovative medical schools, "Towards Unity for Health". The University effectively advocated for national level adoption of the approach as an educational strategy in all higher education institutions in Ethiopia. The effort resulted in endorsement of the approach as a national strategy by Ministry of Education in 2000 under a new name "Community-Oriented Practical Education (COPE)" which is now being implemented in all public universities with some degree of variation between individual universities in terms of scope and intensity. As pioneering institution, Jimma University is still considered to be the national reference institution for the CBE approach and strategy in the country.

The concept of community engagement is strongly embedded in the philosophy of CBE; the latter, among other things, enhances the responsiveness of education to the felt needs of the society by way of relevant educational programs and teaching methods, problem solving research undertakings, and integration of service with teaching and research activities of the University. The CBE educational approach is the hallmark of the University and it permeates and integrates the teaching, research and service activities of the University. It is a means of ensuring quality and relevance of its educational programs to the national development agenda and felt needs of the society by training students in the community exposing them to the real life situations prevailing in the community. The approach takes the students through distinct problem-solving steps that impart the students with skill and attitude necessary to work with the community and contribute to overall societal development.

Currently, CBE is a key strategy that transcends disciplinary and programmatic boundaries in the University from health to engineering, from humanities to natural sciences and from undergraduate to postgraduate programs; it is considered to be part of the institutional identity of Jimma University. In mainstreaming CBE into all educational programs, careful steps were taken to appreciate the specific and unique nature of each discipline and, then, $\mathrm{CBE}$ is adapted to the specific needs of each discipline exercising the necessary pragmatism and understanding the dynamism required to inculcate the principles and attitudes underlying the philosophy. It involves learning activities that use community extensively as a learning environment in a process that involves not only the students but also the teachers, community and other sectors; this creates a unique and robust learning environment and opportunity for collaborative action for community development. The $\mathrm{CBE}$ has three key strategies better known as the $\mathrm{CBE}$ Programs, namely, Community Based Training Program (CBTP), Team Training Program (TTP) and Student Research Program (SRP) which are the three pillars of the educational philosophy of 
CBE. Each student undergoes these programs from year one all the way to graduation in a sequential and spiral manner.

\section{Community Based Training Program (CBTP)}

As one of the programs of CBE, CBTP is introduced early on in the curriculum starting from first year of enrolment and continuing till final year, repeating every year in sequential and spiraling manner. Each year the students go out to the community on a daily basis in a group and are attached for at least four weeks and engage themselves in developmental needs of the community. Every year the same group of students is assigned to the same locality so that they can understand the prevailing problems of the locality and can work on the problem and develop interventions by working together with the community and stakeholders.

\section{Team Training Program (TTP)}

The second program in CBE is Team Training Program (TTP). Students undergo this program during their final year; they are assigned in teams constituted from various disciplines and posted in one of training health centers in the region for a period of $8-10$ weeks. The TTP program is a comprehensive approach for ensuring that health personnel competently perform the task relevant to the health needs at the health centre level. It enables to work as a member of a team in solving community problems based on comprehensive primary health care initiatives by applying the knowledge and skills of their profession and integrating these with the knowledge and skills of other members. Jimma University has been implementing TTP since 1989 including the period during the former JIHS, nearly for two decades. As health disciplines were the major training programs at the time, the teams were constituted from health science fields. But as the University continued to expand and as new non-health disciplines were opened the need to expand the team beyond health disciplines has become imperative. Consequently the University has launched what is known as Development Team Training Program (DTTP) which almost refers to the TTP organized to include both health and non-health disciplines. The underlying thinking is that team skill is crucial in future performance of the graduates and societal problems are more complex than monolithic disciplinary silos in which we train students; social problems present in a more complex way that requires multidimensional response based on interdisciplinary collaboration. The team works together in collaboration with community and other actors in defining problems of the community, generating alternative solutions, implementation of the interventions and monitoring and evaluation of the intervention. Through the process team members acquire the skill of working as a team and appreciation of the role and contribution of other disciplines in addressing the problem, the quality crucially important in world of work ahead of the graduates.

\section{Student Research Project (SRP)}

As a requirement for graduation students carry out research projects at the end of their $\mathrm{CBE}$ attachment usually during the final year; therefore, SRP is the third and also very important CBE strategy considered to be the culmination of student learning experience in the University, both in the community and classroom. The students select a topic for their research during their CBE activities in the community, from didactic sessions and other individual learning opportunities. All degree program students are required to do an independent research work. This enables the students to be skilled researchers. While doing their research they will gain knowledge on problem identification, data collection, data analyses, proposing solutions and implementation. 
The same to CBTP and DTTP, SRP is a community based study which follows sound and ethical procedures aiming at solving the prevailing problems of the community in action oriented manner. The project should not be an expensive to finance by the university. This research project will be a springboard for future elaborate research students would carry out in real life situation. Research advisors will be assigned for each student researcher.

\section{Community Engagement in Jimma University}

Jimma University is committed to community oriented education and promotes integration of teaching and research with service; as a result educational delivery, research undertaking and provision of service to public are all instrumental to creating and strengthening the bridge between the University and the community. Community engagement is critically important and receives unrivalled emphasis in the University in all its endeavors primarily because of the preponderance CBE approach as a key strategy to ensure relevance and appropriateness of the university education, research and service to the felt needs of the society by creating an interactive learning environment beneficial to all parties in the process: the students, community and other development sectors. The community engagement in Jimma University context is represented in the framework shown in Figure 2. The implementation of community engagement is shaped to a large extent by the education approach it follows: the CBE. In this educational approach all stakeholders, that is, the University, the community, the students, the staff and other sectors should benefit from the engagement. In University's context the "community" is considered to be any entity that interacts with the University through its three core functions: teaching and learning, research and scholarship and provision of service to the public, from individuals to organizations, from households to government and from NGOs to businesses. The community engagement takes many forms and has a number of benefits to the University and stakeholders. Some of these benefits include:

1. Social awareness and civic responsibility: in the process of working with the community staff and students get awareness about problems and needs of the community and feel commitment to their responsibilities and sense of social service. In countries like Ethiopia this attitude is crucial to nurture willingness to work for the societal development to fight poverty and backwardness that had grip on the majority of the people.

2. Enhancing educational quality and relevance including student team skills: supporting theoretical classes with exposure to real life problems and application of didactic knowledge and skills to solve community problems enhances the relevance of education and quality of educational programs provided by the University.

3. Enriching teaching and learning experience: staff and student participation in community engagement through $\mathrm{CBE}$, research and consultancy helps in developing teaching materials with local relevance and illustrating teaching with appropriate field experiences. Students work as a multidisciplinary team on problems prevailing in the community which gives them experience on how to work as team for better result.

4. Provision of services: as outlined in the following section the community gets a number of services from the staff and students including health services, community based interventions, training and capacity building and community education.

5. Revenue generation: from community engagement the university also supplements its resources from revenue it receives from community engagement activities such as 
consultancy services, continuing and distance education and university-industry interaction.

6. Contribution to local development: Jimma University is playing a significant role in the ongoing development and poverty reduction efforts in the locality. Through its CBE programs it supports community based small projects in partnership with the community, the local government, NGOs and civil society. It also provides technical support to small businesses and disseminate information on development-relevant issues.

FIGURE 2

\section{CBE APPROACH AND COMMUNITY ENGAGEMENT IN JIMMA UNIVERSITY: A CONCEPTUAL FRAMEWORK}

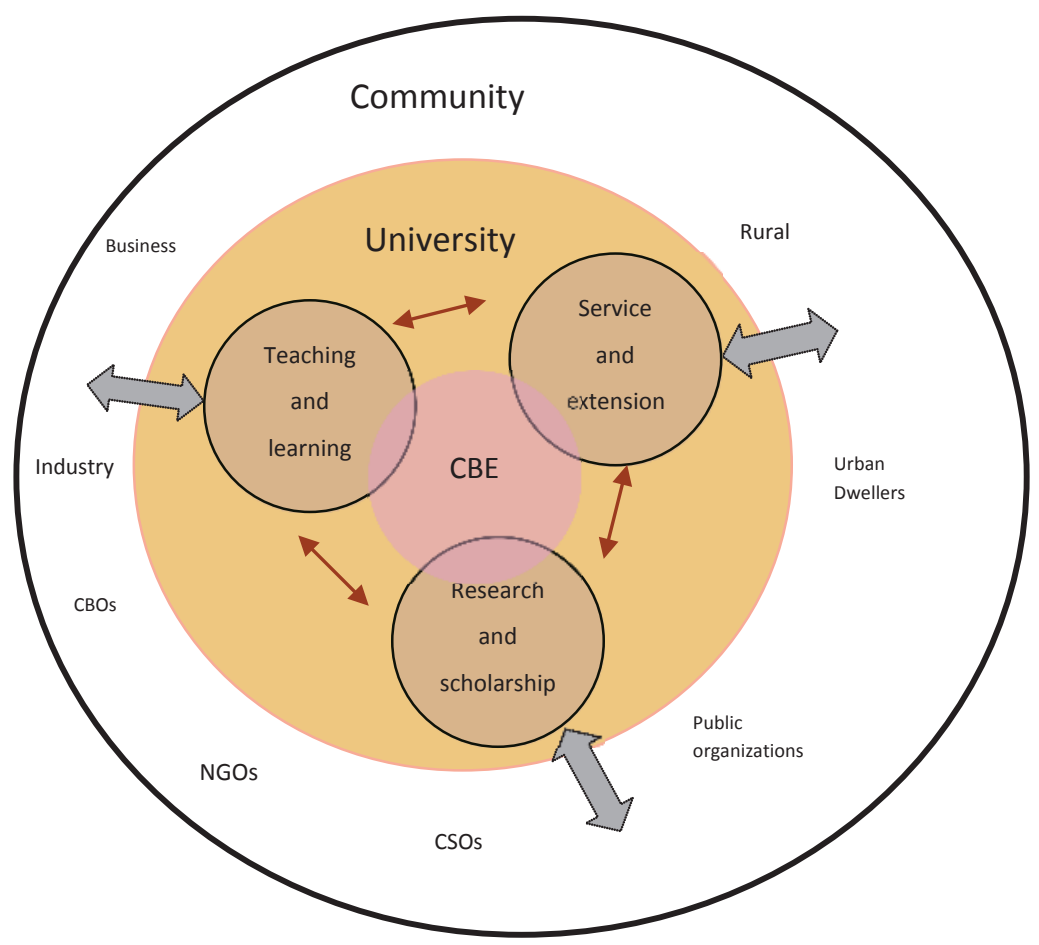

\section{Modalities of Community Engagement}

An important aspect to appreciate when one considers community engagement in Jimma University is prominence of the concept from the very beginning and the degree of conceptual overlap with CBE. The importance of community as a learning environment and a beneficiary of this interaction was part of founding document of Jimma Institute of Health Sciences (JIHS), the founding institution of Jimma University. Though the initial emphasis was more on university community interaction as a way of making the education relevant to societal needs and problems, and as a means of contributing to local development, especially in the health fields, there was clear evidence that community engagement was central to the teaching and research operations of JIHS. When the University was established in 1997 the tradition of community engagement nurtured under the CBE approach was adopted for the new university with progressive expansion of the approach to other disciplines beyond medicine and health sciences. 
Today community engagement, powered with the philosophy of CBE, takes many forms in Jimma University, e.g.

1. Development works in the community: during their internships to the community staff and students closely work with the community and other development sectors to address the priority problems identified through active participation and ownership of the community. Depending on the priority problem identified by the community with support of the students and staff of the University, development interventions are proposed within available community resources with some inputs from the University. Corresponding to the identified problem these development works could be protection of springs, dipping latrines, incinerators, digging water wells, vector control, mass deworming, distribution of ITN, developing micro-hydroelectric dams, support to schools, liaisoning the community with NGOs and development agencies, and so on.

2. Direct provision of services to the community: in addition to traditional services provided by the university hospital, the university provides health services directly to the community in one of eight training health centers and five affiliated hospitals outside Jimma town; mature students from different disciplines are posted in these institutions to provide the services. Also, a variety of services is free of charge for the specific groups; the Community Resources Center (CRC) for IT services provides professional advice to SMEs and community based micro-enterprises. The university has also been active in the areas of emergency response such as drought, floods and epidemics by fielding professionals and providing logistic support.

3. Community education: development information is short supply in the community. Jimma University has been active in this particularly area by providing information and education about disease prevention and control, fighting harmful traditional practices, female education, legal education and rights, prevention and control of HIV/AIDS, environment and population. At the moment the University has established a community FM radio to provide information and education to the community; the latter participate in the programs in turn as volunteers and as actors.

4. Capacity building and life-long learning: the university closely work with local, regional and federal governments to provide capacity building in the form of tailored training programs, research consultancies and continuing and distance education, but not limited to these areas.

5. Working with businesses and promoting entrepreneurship: working with businesses is a new and emerging area in the university-community interaction compared with other areas where the university has decades of experience. With all its challenges, however, it is a growing and quite promising area. At the moment the University is sending senior students to industry for professional attachment, has started developing locally appropriate technologies and discussing with industry for commercialization, working with agricultural enterprises for research and production of seeds, currently the University is producing maize. It is also other partners (GIZ) for propagation of microhydro-electric power to the rural Ethiopia.

The typology and number of university-community interaction are numerous; what we tried to mention above are only the common and visible ones. The transformation agenda (20062015), and the strategic plan of Jimma University clearly indicate the prominence of the third 
dimension (community engagement) in the future of the University. According to observations of many, Jimma University is very much in the community compared with an average university. Of course the teaching and learning has benefited from this engagement. In one of the studies that evaluated and compared medical doctors who graduated from Jimma Institute of Health Sciences (now Jimma University) with graduates of conventional medical schools in the country revealed that the impact of CBE on the graduates of the Institute- now Jimma University-is quite observable in terms of attitudes towards working with the community, practicing community-oriented activities, commitment and character to serve the society.

\section{CONCLUSION}

Jimma Institute of Health Science, the forerunner of the current Jimma University, was intended to be different from traditional institutions of higher learning in the country from its very inception. It introduced innovative curricula that promote university-community interaction in the scale never tried before in Ethiopia by using community as a teaching and learning, research, and service and extension site with active involvement of the community. Today, the CBE legacy of the Institute has been extended to each and every program in Jimma University and CBE has become the hallmark of the University. With CBE, community engagement takes an extra dimension in terms of intensity and emphasis which has created an extraordinary opportunity to engage with the community. Community engagement has not only contributed to quality and relevance of education in the University it has also enabled the University to discharge its civic responsibilities by actively involving in socio-economic development of the local community and country at large.

Community engagement and CBE are very important, nevertheless hard to implement. The resource-intensive nature of both has led to disillusionment and reluctance from many universities in the country. The Jimma University experience demonstrates that with strong leadership and institutional support community engagement can be practiced even with limited resources available to universities; in countries like Ethiopia community engagement is a crucial strategy to impact economic development and growth of the country. It is very important, however, to realize that community engagement is still not well developed in higher education institutions of the country; it is still an emerging area that need substantial commitment.

\section{Community Engaged University in Ethiopia}

All universities are involved in the classic three tasks: education, research and "engagement with the community". Ethiopian universities have embraced the idea of community engagement, especially and primarily in the educational curricula, some universities are in the process of implementation of those ideas (such as the Jimma University case shows). However, the idea of community engagement has not (yet) been extended to research. Other studies (e.g. Woldetensae, 2006) indicated a lack of contact between universities and industries; this is certainly a domain that needs attention of the universities. The data of the questionnaire study indicate that all ("old") universities in Ethiopia have their income from governmental sources. The respondents see the (potential) harvest from the community via community engagement as substantial for the individual staff member as well as for the university. Nevertheless, community involvement is strategic (part of the mission; related to Clark's 'strengthened steering core") and profitable ("diversified funding base"), but not (yet?) a widespread idea ("commitment to service") that is in the "veins" and the "tissue" of universities, as is shown in the Jimma University case. In the 
university are small nuclei that interact with the outer world (Clark: "developmental periphery"). A challenge for Ethiopia is to bring "research" into community engagement. Engagement is the partnership between a university's knowledge and resources with those of the community to enrich both.

The idea travelled over the globe (via processes of disembedding, reembedding and embedding) and it merged with others. Nevertheless, community engagement is whatever guise is or will be part of every university and academic life.

\section{REFERENCES}

Addis A. (2009). CBE at Jimma University: Conceptual Basis, Historical Development, Current Status and Future Trends. Jimma University.

Ashcroft, K. (2005). 13 New Higher Education Institutions for Ethiopia: Preliminary analysis and discussion of the research into curriculum, resource and organizational issues. Higher Education Strategic Center, www.higher.edu.et.

Association of Commonwealth Universities (2001). Engagement as a Core Value for the University: A Consultation Document. London: Association of Commonwealth Universities.

Bender, G. (2008). Exploring conceptual models for community engagement at higher education institutions in South Africa. Perspectives in Education, 26(1), 81 - 95.

Bringle, R. (1999). Colleges and Universities as Citizens. Boston, MA: Allyn and Bacon

Bringle, R.G. and Hatcher J.A. (2004). Advancing civic engagement through service-learning. In M. Langseth and W.M. Plater (eds), Public Work and the academy: An academic Administrators Guide to Civic Engagement and Service Learning. Boston, MA: Anker Press.

Clark, B. (1997). Creating Entrepreneurial Universities. Oxford: Pergamon.

Clark, B. (2003). Sustaining Growth in Universities. London: Open University Press.

Community Based Education Office (2004). Revised CBE guideline. Jimma University.

Czarniawska, B., \& Joerges, B. (1996). Travels of Ideas. In B. Czarniawska, \& G. Sevon (Eds.), Translating Organizational Change. Berlin: de Gruyter.

Davies, J.L. (1987). The entrepreneurial and adaptive university - report of the second US study visit. Journal of the IMHE, 11, 12 - 104.

Demissie A. (2000) Historical account, establishment and achievement, current status and future visions of $J U$. Paper presented to the National workshop on practical training in higher education institutions in Ethiopia. 20-21 March 2000. Jimma University. 
Etzkowitz, H. (2008) The triple helix: university-industry-government innovation in action. New York: Routledge.

Grit, K. (2000). Economisering als probleem [Economizing as a problem]. Assen: Van Gorcum.

Holland, B.A. (1997). Analyzing Institutional Commitment to Service. Michigan Journal of Community Service Learning, 4, 30 - 41.

Powell, J. (2007). Creative universities and their creative city-regions. Industry \& Higher Education, 21 (5), 323 - 336.

Kebede K. (2000). The Genesis of Community Based Education (CBE). Paper Presented to the National Workshop on Practical Training in Higher Education Institutions in Ethiopia. 20-21 March 2000. Jimma University.

Kellogg Commission (2001). Returning to our roots: the engaged university. Executive summaries of the reports of the Kellogg Commission on the future of State and Land-Grant Universities. Washington, DC: National Association of State Universities and Land-Grant Colleges.

Tornatzky, L.G. et al. (2002). Innovation U. New university roles in a knowledge economy. Southern Growth Policy Board.

Yizengaw, T. (2007). The Ethiopian higher education: creating space for reform. Addis Abeba: private publication.

Wissema, J.G. (2009). Towards the third generation university. Cheltenham: Edward Elgar

Woldetensae, Y. (2006). University-Industry Linkage for Promoting Quality Higher Education in Ethiopia. Paper presented at the Triple Helix conference "Transforming university-industry government relations in Ethiopia", Addis Ababa, 29th - 31st May.

World Bank (2003). Higher Education Development for Ethiopia: Pursuing the Vision. Washington: World Bank. 